\title{
Appraisal of HIV/AIDS Information and Usefulness among Senior Secondary School Students in Zaria Town, Kaduna State, Nigeria
}

\author{
Suleiman, M. S. \\ Department of Sociology and Anthropology, Faculty of Humanities and Social Sciences, Khon Kaen University, Khon Kaen, Thailand
}

Copyright $(2018$ by authors, all rights reserved. Authors agree that this article remains permanently open access under the terms of the Creative Commons Attribution License 4.0 International License

\begin{abstract}
A study to appraise HIV/AIDS information and its usefulness among senior secondary students in Zaria town, Kaduna State of Nigeria was undertaken. Senior secondary school students in Nigeria are mostly teenagers and are more often than not interested in sexual relationships. The adolescents at this period may want to test sex without much consideration of the end result of engaging in such actions. It may be noticed that HIV/AIDS is one of the greatest challenges to sustainable economic, socio-cultural and political development of any civilization. It is acknowledged fact that the adolescents of today are leaders of tomorrow; therefore, for a meaningful sustainable development to be attained in any society, young people are required to live healthy lives. Therefore, social survey research was adopted for this research work. A sample of 240 students, across 8 selected senior secondary schools in Zaria town was used as the population sample. The questionnaires were coded and analyzed using the SPSS software. The data collected was then subjected to simple descriptive statistical analysis. The study revealed that majority of the respondents had knowledge of HIV/AIDS, but are reluctant to submit themselves to HIV/AIDS test. Most of the respondents are aware of the various mode of transmission of HIV/AIDS as well agreed that use of condom as a mode of prevention. It was also noted that the students' sources of information and their effectiveness were through posters and pamphlets. The study concluded by recommending that the government and other stakeholders should technically strategize on HIV/AIDS campaign initiative in secondary schools. HIV/AIDS policy should be initiated and implemented for sustainable development. As a matter of policy, all secondary schools in the state should have a functional HIV/AIDS club.
\end{abstract}

Keywords Appraisal, HIV/AIDS, Information, Senior Secondary Schools, Sustainable Development

\section{Introduction}

AIDS is an acronym for Acquired Immune Deficiency Syndrome resulting from infection by Human Immunodeficiency Virus (HIV) that invades and cripples the immune system as well as exposing the infected person to live threatening opportunist infections. The population of People Living with HIV/AIDS (PLWHA) globally has leveled off at 37 million. Nigeria as the most populous nation in Africa continent remains one of the most burdened nations with about 3.6 million people living with the epidemic. By inference Nigeria has the largest second burden of HIV infection in the world; it contributed $9 \%$ of the People Living with HIV, $10 \%$ of new infections and $14 \%$ of HIV related death in the world. In addition, the worst affected group are young people aged 15-24 years and female $[1,2]$.

In a related development, it is revealed that the leading route of HIV/AIDS transmission in Nigeria has been through heterosexual activities, the risk of transmission of HIV is largely determined by sex outside stable relationship, mother to child, then men who have sex with men and people who inject drugs. However, the virus called HIV can be transmitted from one person infected to another person through sexual intercourse as well as sharing of unsterilized sharp instruments or tools such as blades, knives, syringes among others which had once been used by the infected person or people [3, 4]. Thus, it can be inferred that it is of immense importance to create necessary awareness among the Nigerian population to be acquainted with all the routes of transmitting HIV, although it is widely asserted that heterosexual activities are the major route of transmitting the epidemic, however, it is equally of enormous importance to make the information available to the Nigerian masses that there are other means or routes of transmitting HIV apart from heterosexual activities, men who have sex with men and people who inject drugs. The other means of transmitting the epidemic are sharing of unsterilized sharp objects or 
instruments such as syringes, clippers, knives, blades among others used by infected person or persons, accepting an unscreened blood transfusion. In addition, it is worth noting that these mentioned sharp objects are commonly used in daily activities in the young people in Nigeria.

Moreover, in spite of the various campaign strategies that have been put in place by both governmental and non-governmental organizations to curb the spread of HIV/AIDS, however, HIV/AIDS has rendered many children to become orphans, many of the children born with HIV infection. They further assert that HIV/AIDS is killing the most productive people in the population, widening the level of development between developed and underdeveloped nations of the world [5]. Therefore, it is expected to create essential responsiveness on the mode of transmitting HIV/AIDS to the young people. However, in efforts to create information about the danger of HIV/AIDS among youth in the society, the senior secondary school students are part of the young people that are expected to be included.

Similarly, it is put forward that HIV testing is the number one step in awareness campaigns in order to reveal the status of that person and to know the next line of action either infected or not infected [6]. In the same way, it was posit that people who are diagnosed with AIDS may get life-threatening diseases called opportunistic infection which is caused by microbes and such make unhealthy people sick but if diagnosed early it can help in the treatment and kind of lifestyle of the infected person [5].

Therefore, since senior secondary school students in their youthful age are mostly involved in sexual relationships. The teens at this moment may want to experience sex without serious reflection on the extent of engaging in such actions. It is pertinent to note that HIV/AIDS is one of the greatest challenges to sustainable economic, socio-cultural and political development of the human race. It is known fact that the teens in the present day are leaders of tomorrow; for this reason, in order to attain a meaningful sustainable development in Nigeria, young people are expected to live healthy lives. Thus, it is essential to provide them with sufficient amount of information which will help them protect themselves from the spread of HIV/AIDS epidemic in the society. Consequently, this research work intends to appraise HIV/AIDS information and usefulness among senior secondary students in Zaria town, Kaduna State of Nigeria.

\section{Statement of the Research Problem}

Since the first discovery of HIV/AIDS epidemic in 1981, the infection has reached epidemic proportion in the world that has turned to short and long terms developmental issues globally. There is no any nation in the world that is not hit by the burden of HIV/AIDS epidemic. It is a common saying that Heath is Wealth, meaning health is central to sustainable development. The above assertion confirms the view of the world leaders of coming up with ideas on how to reduce child mortality, improve maternal health, combat HIV malaria and other diseases as one of the targets of the Millennium Development Goals (MDGs).

The Millennium Development Goals (MDGs) refers to eight goals for development adopted by the world leaders at the United Nations to address problems affecting the world, such as poverty, women empowerment, education, health, environmental degradation and child mortality with the aim of bringing development through improving people's social and economic conditions, more especially in the world's poorest nations [7, 8]. However, it is worth noting that the Millennium Development Goals (MDGs) has developed to what is now called Sustainable Development Goals with seventeen goals. The third goal of the Sustainable Development Goals focused on the Good Health and Wellbeing, which the fight against the spread of HIV/AIDS fall under this goal. However, despite many programmes organized by various stakeholders in order to inform people on the danger of HIV/AIDS in the society, the rate of the infection of the epidemic is still on the high side. In a related development, HIV/AIDS has become a public health threat that deserves urgent attention since it is unfinished business.

In addition, it is affirmed in HIV/AIDS-related matters have a serious effect on human capital development triggering unbearable illness and death in people during their crucial years of life and has distressed families and societies. The epidemic has increased poverty, promoted ill-health, retarded development and diminished a person's ability to support, work and provide for his or her family and women and children are at a high risk of infection [9,10]. Therefore, it worth noting that information is believed to be power; it increases the level of confidence in all human endeavours as well as the process of making an informed decision. HIV/AIDS information is the most effective weapon accessible in the management and prevention of HIV/AIDS in the society [11]. In a related development, HIV/AIDS information is indispensable for human development in any society, therefore current HIV/AIDS information and education should be pursued with all seriousness since every individual either infected or not infected with epidemic desires information about HIV/AIDS to survive[12-16].

It is therefore pertinent to note that HIV/AIDS is a threatening epidemic in Nigeria and the entire universe; it has no cure for now. More people are infected or affected by HIV/AIDS daily which has severe economic, social and political consequences in the nation in achieving sustainable development. Hence, it is imperative to furnish senior secondary school students in Zaria town, Kaduna State in particular and that of Nigeria in general with ample amount of information which will help them 
protect themselves from the spread of HIV/AIDS pandemic in the society.

\section{Aim and Objectives of the Study}

The aim of this study intends to assess HIV/AIDS information and usefulness among senior secondary students in Zaria town, Kaduna State of Nigeria. While the specific objectives of the study examined if the senior secondary school students in Zaria town, Kaduna State have information about HIV/AIDS, find out the sources of information that are available to the students, determine the usefulness of these sources and make recommendations to obtain useful information regarding HIV/AIDS epidemic.

\section{Theoretical Framework}

The theoretical framework adopted for this study is Functionalist perspective. HIV/AIDS is a social phenomenon that has been growing at a rapid rate since when it was discovered in the 1980s. From the functionalist perspective, young people are not the only ones who need to be educated about HIV/AIDS. Patients who are diagnosed with HIV/AIDS also rely on education regarding treatment options, expenses, symptoms, and so forth. On the other hand, people who are not HIV-positive should also be getting educated and practicing prevention measures. Having a blood screening at yearly physicals might also cut down on the rapid spread of AIDS. Annual testing could also be controversial because some people might argue that getting tested yearly is not necessarily advantageous. Sometimes the HIV virus doesn't show up in blood until years later and people can be carriers; spreading the disease unknowingly. According to the functionalist, these measures of strengthening the health care system would show great progress in slowing the rapid spread of AIDS. According to the structural-functionalist perspective, health care is a social institution that functions to maintain the well-being of societal members and, consequently, of the social system as a whole [17].

The functionalist views the rapid spread of AIDS as major dysfunction in our society and they build their solutions to this social problem at the macro level. In order to mitigate the impact of HIV/AIDS in the society, everyone including secondary school students is expected to be tested for HIV/AIDS regularly and inform children (secondary school students) and adults about the potential dangers of unprotected sex and HIV/AIDS. The functionalist solution works best to solve the problem of the rapid spread of AIDS because it makes people aware of the issue and pushes society to work toward a common goal. Since HIV/AIDS is a major universal problem that involves many social institutions, the functionalist perspective has the best solution as it works at the macro level and strives to strengthen weakened social institutions; like the government, family, schools, and healthcare.

The education of young people is essentially significant in reducing the spread of HIV/ AIDS because HIV/AIDS education is cost-efficient and "an effective social vaccine against the further spread of the epidemic called HIV/AIDS. The risk of HIV/AIDS infection is more than halved for young people, particularly girls, who stay in school and complete a basic education [17]. However, education plays a significant function in reducing the further spread of HIV/AIDS, but regular testing could also prove more successful, when people are tested for HIV/AIDS regularly, it would assist reducing the spread of AIDS [18].

By inference, functionalist perspective is suitable for this research, by stressing the need to make available vital information through education to masses which the secondary school students are part the danger of HIV/AIDS epidemic to the society in order to achieve sustainable development in Nigeria. Therefore, it is vital to provide senior secondary school students in Zaria town, Kaduna State in particular and that of Nigeria in general with sufficient amount of information can assist them to make an informed decision on how to protect them from the spread of HIV/AIDS epidemic in the society.

\section{Methodology}

The methodology adopted for this research work was the social survey technique. A random sample of 240 students, across 8 selected senior secondary schools in Zaria town, Kaduna State was used as the population sample. Purposive stratified sampling technique was adopted by the researcher. The eight senior secondary schools in Zaria used were: Barewa College, AL-Huda Huda College, Government Science Secondary School, Kufena, Federal Government Girls' College, Government Girls Secondary School (Senior), Government Secondary School, Jama’a, Government Commercial College and Government Secondary School, Bomo respectively while 30 students were randomly selected from the selected schools and 30 questionnaires were purposively distributed and administered to the respondents within each of the selected schools for this research work through the aid of some teachers as volunteers. The questionnaires were coded and analyzed using the SPSS software. The data collected for this study was then subjected to simple descriptive statistical analysis.

\section{Data Presentation}

In this section, the data on Assessment of HIV/AIDS Information and Effectiveness among senior secondary school students in Zaria town, Kaduna State, Nigeria are presented in the tables below. The respondents' responses are summarized and interpreted as follows: 
Table 1. Bio-Data of the Respondents

\begin{tabular}{|c|c|c|}
\hline Variable & Frequency & Percentage \\
\hline Gender & & \\
Male & 144 & 60 \\
Female & 96 & 40 \\
\hline Age Group & 22 & \\
$10-15$ & 206 & 09 \\
$16-20$ & 12 & 86 \\
$21-25$ & 00 & 05 \\
$26-30$ & 180 & 00 \\
\hline Marital Status & 47 & 75 \\
Single & 13 & 20 \\
Married & 177 & 05 \\
Divorce & 63 & 74 \\
Religion & & 26 \\
Islam & 47 & 19 \\
Christianity & 117 & 49 \\
\hline Class & 76 & 32 \\
\hline SS1 & & \\
SS2 & & \\
SS3 & & \\
\hline
\end{tabular}

Source: Field Work (2016)

Table 1 above revealed the bio-data of the respondents; it is clear that from the study, the male population is greater than that of the female. This can be linked to the historical background of female low educational status in Northern Nigeria. Majority of the respondents were under the age group 16-20 years showing clearly most of them are teenagers. Their marital status illustrated that most of the respondents are single. The table also indicates that most of the respondents practice Islam. Since Zaria town is known as the centre of Islamic knowledge for long. Data on class in the school of the respondents' shows that majority of them are in SS2.

Table 2. Awareness of HIV/AIDS information in your School

\begin{tabular}{|c|c|c|}
\hline $\begin{array}{c}\text { Are you aware of HIV/AIDS information } \\
\text { in your School? }\end{array}$ & Frequency & Percentage \\
\hline Aware & 209 & 87 \\
\hline Not aware & 25 & 10 \\
\hline No response & 06 & 03 \\
\hline
\end{tabular}

Source: Field Work (2016)

Table 2 above illustrates that majority of the respondents are aware and have information about HIV/AID knowledge through frequent HIV/AIDS information available in the schools. It is only $10 \%$ of the respondents that were not aware of the HIV/AIDS campaigns while $03 \%$ of the respondent failed to respond.

Table 3. Awareness of HIV/AIDS Status

\begin{tabular}{|c|c|c|}
\hline Are you aware of your HIV/AIDS Status? & Frequency & Percentage \\
\hline Aware & 49 & 20 \\
\hline Not aware & 187 & 78 \\
\hline No response & 04 & 02 \\
\hline
\end{tabular}

Source: Field Work (2016)

Table 3 above indicates that majority of the respondents were not aware of their HIV/AIDS status despite they were fully aware of HIV/AIDS campaigns. Only 20\% of the respondents were aware of their HIV/AIDS status and 02\% of the respondents failed to respond. Thus, the majority of the respondents do not have adequate information about their HIV/AIDS status.

Table 4. Reasons for Unwillingness to Know HIV/AIDS Status

\begin{tabular}{|c|c|c|}
\hline $\begin{array}{c}\text { What are the reasons for Unwillingness to } \\
\text { Know HIV/AIDS Status }\end{array}$ & Frequency & Percentage \\
\hline Prefer not to know & 17 & 07 \\
\hline Fear of death & 24 & 10 \\
\hline Fear of been positive & 41 & 17 \\
\hline Fear of been stigmatized & 156 & 65 \\
\hline No response & 02 & 01 \\
\hline
\end{tabular}

Source: Field Work (2016)

Table 4 revealed that majority of the respondents feared stigmatization as their major reason of not willing to know their HIV/AIDS status, while $17 \%$ feared of being positive, $10 \%$ were feared of death and $07 \%$ preferred not to know their HIV/AIDS status. $01 \%$ of the respondents did not respond. Meaning there is needed to provide the students with ample information on the danger of HIV/AIDS-related stigma on prevention and management of HIV/AIDS in the society.

Table 5. Information on the Modes of Transmitting HIV

\begin{tabular}{|c|c|c|}
\hline $\begin{array}{l}\text { Are you aware that HIV can be } \\
\text { transmitted from one infected person to } \\
\text { another through sexual intercourse and } \\
\text { sharing of unsterilized instruments like } \\
\text { blades, knives, and syringes which had } \\
\text { once been used by the infected person? }\end{array}$ & Frequency & Percentage \\
\hline Aware & 208 & 87 \\
\hline Not aware & 27 & 11 \\
\hline No response & 05 & 02 \\
\hline
\end{tabular}

Source: Field Work (2016)

Table 5 illustrates that most of the respondents were having information that HIV can be transmitted from one infected person to another through sexual intercourse and sharing of unsterilized instruments like blades, knives, and syringes which had once been used by infected person and especially those sharp objects injure the infected person while $11 \%$ of the respondents is not having the information. $02 \%$ of the respondents did not respond to the question.

Table 6. Information on the Modes of HIV/AIDS Prevention

\begin{tabular}{|c|c|c|}
\hline Mode of Prevention & Frequency & Percentage \\
\hline Use of condom & 52 & 22 \\
\hline Abstaining from pre/extramarital affairs & 129 & 54 \\
\hline Not sharing sharp objects & 35 & 14 \\
\hline Isolation of victims from others & 21 & 09 \\
\hline No response & 03 & 01 \\
\hline
\end{tabular}

Source: Field Work (2016) 
Table 6 shows that majority of the respondents agreed on abstaining from pre and extramarital affairs as mode of preventing HIV/AIDS while $22 \%$ of them agreed on use of condom, 14 of respondents agreed on not sharing sharp objects and 09\% believed in isolation of HIV/AIDS victims from other which is another form of stigmatization. 01 of the respondent failed to respond.

Table 7. Sources of HIV/AIDS Information Available to Respondents

\begin{tabular}{|c|c|c|}
\hline Sources of HIV/AIDS Information & Frequency & Percentage \\
\hline Posters/pamphlets & 39 & 16 \\
\hline Radio/television & 103 & 43 \\
\hline Friends/classmates & 13 & 05 \\
\hline Internet & 27 & 11 \\
\hline Newspapers/magazines & 10 & 04 \\
\hline Religious gatherings & 41 & 18 \\
\hline No response & 07 & 03 \\
\hline
\end{tabular}

Source: Field Work (2016)

Table 7 revealed that majority of the respondents was of the view that radio/television as the most common source, since listening and watching radio and television is a common thing in Northern Nigeria. $18 \%$ of the respondents attributed their source to religious gatherings, $16 \%$ to posters/pamphlets, $11 \%$ to the internet, $05 \%$ to friends/classmates $04 \%$ to newspapers/magazines. Then, $03 \%$ failed to respond.

Table 8. Regularity of Sources of HIV/AIDS information to the Respondents

\begin{tabular}{|c|c|c|}
\hline $\begin{array}{c}\text { How often do you receive HIV/AIDS } \\
\text { information from the sources above? }\end{array}$ & Frequency & Percentage \\
\hline Often & 189 & 07 \\
\hline Rarely & 43 & 18 \\
\hline No response & 08 & 03 \\
\hline
\end{tabular}

Source: Field Work (2016)

Table 8 demonstrates that most of the respondents often receive HIV/AIDS information from these sources while $18 \%$ of the respondents indicated that they rarely get HIV/AIDS information from these sources.

Table 9. Effectiveness of the Sources of HIV/AIDS information to the Respondents

\begin{tabular}{|c|c|c|}
\hline $\begin{array}{c}\text { Effectiveness of the Sources of HIV/AIDS } \\
\text { Information }\end{array}$ & Frequency & Percentage \\
\hline Posters/pamphlets & 29 & 12 \\
\hline Radio/television & 113 & 48 \\
\hline Friends/classmates & 13 & 05 \\
\hline Internet & 17 & 07 \\
\hline Newspapers/magazines & 20 & 08 \\
\hline Religious gatherings & 46 & 19 \\
\hline No response & 02 & 01 \\
\hline
\end{tabular}

Source: Field Work (2016)
Table 9 above revealed that majority of the respondents were of the view that radio and television are the most effective sources of getting HIV/AIDS information while $19 \%$ were of the view that it is religious gatherings, $12 \%$ posters/pamphlets, $08 \%$ newspapers/magazines, $07 \%$ internet and $05 \%$ friends/classmate. $01 \%$ of the respondents did not respond to the questions.

\section{Discussion}

This study revealed that that majority of the students in senior secondary school in Zaria town, Kaduna State have information and familiar with HIV/AID knowledge through frequent HIV/AIDS information available in their schools confirming the work Ilo et.al (11) that HIV/AIDS information is the most effective weapon accessible in the management and prevention of HIV/AIDS in the society. Despite the level of awareness of HIV/AIDS Information among the students, majority of them were not having information about their HIV/AIDS status and feared stigmatization as their major reason of not willing to know their HIV/AIDS status, this corroborates the scholarly works that stigmatization of PLWHA has harshly hindered the fight to effectively combat HIV/AIDS epidemic because stigma remains one of the main reasons why many people are afraid to see a physician in order to find out their HIV/AIDS status or seek medical attention or treatment in the case of being infected with HIV/AIDS. In addition, most of the respondents were aware that HIV can be transmitted from one infected person to another through sexual intercourse and sharing of unsterilized instruments like blades, knives, and syringes which had once been used by infected person when it injure the infected person and equally majority of the respondents agreed on abstaining from pre and extramarital affairs as mode of preventing HIV/AIDS [10, 19-23]. Furthermore, the majority of the respondents were of the view that radio/television are the most common and effective sources of getting HIV/AIDS information since listening and watching radio and television is a common practice among the people of Northern Nigeria. This corroborates that HIV/AIDS information is indispensable for human development in any society, therefore current HIV/AIDS information and education should be pursued with all seriousness since every individual, either infected or not infected with epidemic desires information about HIV/AIDS to survive [12-17].

\section{Conclusions}

HIV/AIDS information and efficient handling of it is a shared responsibility that is not limited to health sector alone but all stakeholders in the society. HIV/AID is a global tragedy with victims all around the globe. Therefore, sufficient information concerning the danger poses by this 
epidemic can lead to effectual management and control of the deadly disease which can lead to positive impact on the socio-economic and political sustainability of the universe. For this reason, sufficient information, resourcefulness, synergy, and teamwork from all stakeholders may be required to mitigate the further spread and management of HIV/AIDS epidemic in the society, especially among the younger people which the senior secondary school students who form the larger part of the population in order to achieve sustainable development necessary for the progress of humanity.

\section{Recommendations}

Based on the findings of this research work, it is recommended that the government and other stakeholders should technically strategize on HIV/AIDS campaign initiative in secondary schools. HIV/AIDS policy should be initiated and implemented for sustainable development. As a matter of policy, all secondary schools in the State and Nigeria should have a functional HIV/AIDS club. In addition, school libraries should be fully equipped with information materials on HIV/AIDS that can easily be accessible by the students. Involvement of secondary school teachers in educating students on the danger of HIV/AIDS as well as including it as part of the national curriculum may help in preventing the further spread and management of the epidemic in Nigeria.

\section{REFERENCES}

[1] National HIV/AIDS Strategic Frame Work 2017-2021.

[2] UNAIDS. Report on the Global AIDS Epidemic. 2017: Retrieved on $15^{\text {th }}$ January, 2018 from http://www.unaids.org/en/dataanalysis/epidemiology/2017r eportontheglobalaidsepidemic.

[3] Adamu, H.Y. AIDS Awareness. 2010: Spectrum Books Limited Ibadan.

[4] Ankomak, A., Adebayo, S.B., Anyanti, J., Ladipo, O., and Omeregie, G. Determinants of condom use by men in extra marital relationships in Nigeria. HIV/AIDS (AUCKL) 2013: 5: 97-109.

[5] Omoniyi, M.B.I. and Tayo-Olajubu, O. Relief from HIV/AIDS: A psychological Approach. 2006: International Journal of Gender and Health Studies Vol. 4. No 1 and 2 Pg 33-42

[6] Cichocki, R.N. Symptoms and Prevention of HIV/AIDS. 2010: Retrieved on $5^{\text {th }}$ May, 2016 from http://aids.about.com/od/hiv101/u/basic.htm

[7] Amin, S. The Millennium Development Goals: A Critique from the South". Monthly Review. 2006: Volume 57. Number 10.
[8] Canning, D.N., Odumosu, K. and Okonkwo, P. Assessing the Economic Impact of HIV/AIDS on Nigerians Household: A Propensity Scare Matching Approach, Programme of the Global Demography of Ageing. 2008: Haward Institute for Global Heath Working Document

[9] Abdullahi, S.A. HIV/AIDS: Knowledge and Reaction Studies in Abdullah, S.A. Mohammed, I.Z. and Casey, C. Studies in Cultural Sociology. 2009: Ibadan: Foludex Printers. Pg. 244- 256

[10] Ilo, P.I., and Adeyemi, A. HIV/AIDS information and awareness among market women: A Study of Olofinmoye Market Sango-Ota, Ogun State, Nigeria.2010: Library Philosophy and Practice. Retrieved $10^{\text {th }}$ July, 2014 from http://unllib.unl.edu/LPP/ilo-adeyemi.

[11] Markus, N.D and Mashi, S.A. Awareness and Opinions of HIV/AIDS among secondary school students in Keffi, Nasarawa." 2008: Unpublished Undergraduate Project submitted to Department of Geography, Nasarawa State University, Nasarawa State, Nigeria

[12] Sa'ad, A.M and Bello, H. The Meaning and Origin of HIV/AIDS, Its Seriousness, Its Drivers and Prevention.Being a paper presented at a three day workshop on HIV/AIDS for Primary School Head Teachers in Borno State, Nigeria organized by REHRAC and funded by Borno State UBE 11- 13 Dec. 2006.

[13] Wagbatsona, V.A and Okejie, O.H. Knowledge of HIV/AIDS and Sexual Practices among Adolescents in Benin City, Nigeria. 2006: Retrieved on $5^{\text {th }}$ May, 2016 in http://wwwbioline.org,br/request?rh06039.

[14] Bankole O.M. and Mabekoje O.O. Awareness and Opinions about HIV/AIDS among secondary school teachers in Ogun State, Nigeria. Scientific Research and Essay. 2008:Vol. 3 No 6. Pg 245- 253.

[15] Edewor, E. Access to health information by people living with HIV/AIDS in Nigeria Library Philosophy and Practice, 2010: Retrieved 28 March 2011 from http://unllib.unl.edu/LPP.edewor.htm

[16] Mooney, Knox, and Schacth. "Theoretical Perspectives." Understanding Social Problems. 2000: http://www.bolender.com/SOC1023G Social Problems/Units/Unit 6 Problems of the Health Care System/Unit 6 Theoretical Perspectives.htm

[17] Global Statistics. Global Statistics. AIDS. Gov. 2012: Retrieved 6 June 2012. From http://aids.gov/hiv-aids-basics/hiv-aids-101/global-statistics /index.html

[18] Nettleon, S. The Sociology of Health and Illness Polity Press.2006:

http//www.amazon.co.uk/Sociology-Health-Illness-Sarah-N ettleon/dp/0745622881

[19] Miller, I. Bishop, D and Stain, M. Relationship Quality among HIV Patients and Their Caregivers AIDS Care 2007: http://dx.dio.org/10.1080/09540120600624278

[20] Polit, D.F and Beck, C.T. Nursing Research: Generating and Assessing Evidence for Nursing Practice $8^{\text {th }}$ Edition Philadelphia: 2008: Lippincoh Williams and Wilkins Publishers 
[21] Pindan, M, Maluwa, A, Nkondo, M, Nyasulu, B.M. and Chilemba, W. Perception of People Living With HIV/AIDS Regarding Home Based Care. 2014:Malawi Journal of AIDS and Clinical Research Vol.4 No2.
[22] Sa'ad, S.M. Combating HIV/AIDS in Nigeria being a paper presented at the National Conference on Social Sciences and the Challenges of the Millennium Development Goals (MDGs) in Africa organized by Faculty of Social Sciences, University of Maiduguri, Nigeria $26^{\text {th }}-30^{\text {th }}$ October, 2008. 